\title{
Correspondence
}

\section{The Anesthesia History Association}

To the Editor:

Anaesthetists with an interest in the history of our specialty are invited to join the Anesthesia History Association. The inaugural meeting of the association will be held during the Annual Meeting of the American Society of Anesthesiologists on October 9th, 1983, from 1800 to 2200 hours in the Atlanta Hilton Hotel.

The goals of the association are to foster communication and fellowship among all with an interest in our heritage, as well as encouraging historical research. A quarterly newsletter already has over two hundred subscribers.

Active membership is offered to residents of Canada, Mexico and the United States of America. For further information prospective members are encouraged to contact:

\section{Dr. Selma H. Calmes,}

Co-Chairman,

The Anesthesia History Association,

5112 Wilderness Lane,

Culver City, CA 90230 U.S.A.

Thank you for the opportunity to introduce your readers to The Anesthesia History Association.

Rod K. Calverley MD

Dept. of Anesthesiology,

University Hospital,

San Diego, Califomia

J.R. Mallby MB B CHIR FFaRCS

Dept. of Anaesthesia,

Foothills Hospital,

University of Calgary,

Calgary, Alberta

\section{The opiate and anti- opiate system: Evidence for involve- ment in withdrawal responses}

To the Editor:

The paper by Manson et al. ${ }^{1}$ is of considerable interest. These authors have suggested that the opioid effect of $\mathrm{N}_{2} \mathrm{O}$ is mediated indirectly via the release of endogenous opioids. This ignores the possibility that $\mathrm{N}_{2} \mathrm{O}$ may act directly at opioid receptors, an idea that cannot be excluded.

There is now considerable evidence that $\mathrm{N}_{2} \mathrm{O}$ does in fact interact directly at the $\mathrm{mu}$ opioid receptor. ${ }^{2}$ This suggestion is further strengthened by findings in radioactive binding studies. These studies have demonstrated that both tritiated dihydromorphine $^{3}$ and naloxone ${ }^{4}$ can be displaced by $\mathrm{N}_{2} \mathrm{O}$ in vitro. Since C.S.F. levels of beta-endorphin are not raised during $\mathrm{N}_{2} \mathrm{O}$ administration, ${ }^{5}$ a direct action of the gas is even more probable.

A dual system has been proposed to explain the bi-modal effect of naloxone in certain circumstances. ${ }^{67}$ This hypothesis postulates the existence of an opiate and anti-opiate system, which are in dynamic equilibrium. It is possible that the bellshaped dose response curve found by Manson et $a l .{ }^{1}$ could be explained in terms of a differential sensitivity of these two systems to naloxone in withdrawal. A similar bell-shaped dose response curve has been reported, where different concentrations of naloxone were used to precipitate withdrawal in rats. ${ }^{8}$ In this case plasma levels of corticosterone were used as an index of the severity of withdrawal in opiate naive rats, after a single dose of morphine. ${ }^{8}$ These withdrawal phenomena provide evidence that the dual system we have 